\title{
Effects of intravenous anesthetics on the phosphorylation of cAMP response element-binding protein in hippocampal slices of adult mice
}

\author{
HAIYING GAO $^{1}$, LINGYU ZHANG ${ }^{1}$, ZHENYI CHEN $^{1}$, SHUNCUI LIU ${ }^{1}$, \\ QINGHONG ZHANG ${ }^{1}$ and BINGXI ZHANG ${ }^{2}$
}

\author{
${ }^{1}$ Department of Anesthesiology, The First Affiliated Hospital of Xiamen University, Xiamen, Fujian 361003; \\ ${ }^{2}$ Department of Anesthesiology, Affiliated Beijing Tongren Hospital, Capital University of Medical Science, \\ Beijing 100000, P.R. China
}

Received September 22, 2017; Accepted April 17, 2018

DOI: $10.3892 / \mathrm{mmr} .2018 .8939$

\begin{abstract}
AMP response-element binding protein (CREB) functions in hippocampal synaptic plasticity and memory formation. However, it remains unknown whether intravenous anesthetics modulate CREB. The present study aimed to examine the effects of intravenous anesthetics on CREB phosphorylation in the mouse hippocampus. CREB phosphorylation was examined in hippocampal slices with and without pharmacological or intravenous anesthetics via immunoblotting. In a dose-response experiment, the concentrations of intravenous anesthetics ranged from $10^{-9}$ to $10^{-4} \mathrm{~mol} / \mathrm{l}$ for $1 \mathrm{~h}$. For the time-response experiment, these slices were incubated with $5 \times 10^{-6} \mathrm{~mol} / \mathrm{l}$ of propofol for $0,1,2,5,7,9,12,15,30$ and $60 \mathrm{~min}$. In order to examine whether CREB phosphorylation could be recovered following washing out the propofol, the slices were incubated in plain artificial cerebrospinal fluid at different time durations following $5 \mathrm{~min}$ incubation with propofol. Propofol, etomidate, ketamine and midazolam inhibited CREB phosphorylation $(\mathrm{P}<0.05)$ in a time- and dose-dependent manner. This inhibition was reversible following the removal of propofol, and was rescued by CREB phosphorylation $(\mathrm{P}<0.05)$. The decrease in CREB phosphorylation revealed additive effects with $100 \mu \mathrm{M}$ of chelerythrine and $20 \mu \mathrm{M}$ of PD-98059, and the etomidate-induced decrease in CREB phosphorylation was blocked by $1 \mathrm{mM}$ of NMDA. However, $0.1 \mu \mathrm{M}$ of phorbol 12-myristate 13-acetate, $50 \mu \mathrm{M}$ of $\mathrm{U} 73122,100 \mu \mathrm{M}$ of carbachol and $10 \mu \mathrm{M}$ of MK801 were ineffective in the anesthetic-induced decrease in CREB phosphorylation. Intravenous anesthetics markedly decreased CREB phosphorylation in the mouse hippocampus, which was
\end{abstract}

Correspondence to: Dr Bingxi Zhang, Department of Anesthesiology, Affiliated Beijing Tongren Hospital, Capital University of Medical Science, 1 Dong Jiao Min Xiang, Beijing 100000, P.R. China

E-mail: zbxtryy@126.com

Key words: cAMP response-element binding protein (CREB), propofol, etomidate, ketamine, midazolam most likely via the protein kinase $\mathrm{C}$ and mitogen activated protein kinase pathways. This suggests that CREB represents a target for anesthetic action in the brain.

\section{Introduction}

Postoperative cognitive dysfunction (POCD) is the deterioration of cognitive performance after anesthesia (and/or surgery), which presents as impaired memory or concentration (1). Its clinical features include deterioration in cognition, disturbance in attention and reduced awareness of the environment, which result in higher morbidity, mortality and greater utilization of social financial assistance. Aging societies can expect an increase in the incidence of POCD (2). POCD is a decrease in cognition measured by neuropsychological tests after anesthesia and surgery (3). In some studies, the incidence of POCD has reached as high as $26 \%$ (4). Furthermore, at seven days after surgery with propofol anesthesia, the incidence of POCD was $29.7 \%$ (5).

It has been considered that cAMP response-element binding protein (CREB) functions in hippocampal synaptic plasticity and hippocampus-dependent long-term memory (6). CREB modulates the transcription of genes, which contain a cAMP responsive element (CRE sites) in their promoters, and appears to represent a key molecule in transforming incoming information into long-term memory (7). Agents that disrupt the activity of CREB specifically block the formation of long-term memory (8). A number of neurotransmitter receptors and signaling pathways, such as protein kinase $\mathrm{C}$ (PKC), phospholipase C (PLC), N-Methyl-D-Aspartate (NMDA) receptors and MAPK/ERK kinase (MEK), contribute to transcriptional activation, and these receptors are coupled to CREB activation through mitogen-activated protein kinase (MAPK) (Fig. 1) (9). The dysregulation of CREB activation and cross-talking among relevant receptor pathways may be responsible for the effects of intravenous anesthetics on cognition.

It has been previously reported that ketamine suppresses not only the morphine-induced phosphorylation of CREB, but also the residue preference (10). A sub-anaesthetic dose of 
propofol causes impairment of spatial memory retention, but not acquisition inability, which was possibly mediated by the inhibition of CREB signaling (11).

CREB may be the common target of anesthetics. The effects of intravenous anesthetics on CREB phosphorylation in hippocampal slices have not yet been studied. CREB phosphorylation studies offer the opportunity to examine potential mechanisms that contribute to POCD. We hypothesize that anesthesia might cause memory impairment by inhibiting the phosphorylation of hippocampal CREB. Previous studies have shown that CREB plays a key role in hippocampal synaptic plasticity and memory formation. However, its role in POCD remains to be determined.

\section{Materials and methods}

Handling procedures were made according to the Guide for the Care and Use of Laboratory Animals. A total of 72 BALB/C mice (both sex, weight: 18-22 g; Capital University of Medical Science, Beijing, China) were used to perform the experiments. Mice were housed on a 12:12 light/dark cycle, with food and water ad libitum. The experimental protocol was approved by the Institutional Animal Care and Use Committee of the Capital University of Medical Science.

Preparation of hippocampal slices and homogenates. Animals were sacrificed by decapitation. The brains were quickly removed, and the hemispheres were separated. Each hippocampi was carefully dissected and incubated in $\mathrm{Ca}^{2+}$-free artificial cerebrospinal fluid (aCSF) $\left[4^{\circ} \mathrm{C}, 116 \mathrm{mM}\right.$ of $\mathrm{NaCl}$, $26.2 \mathrm{mM}$ of $\mathrm{NaHCO}_{3}, 5.4 \mathrm{mM}$ of $\mathrm{KCl}, 0.9 \mathrm{mM}$ of $\mathrm{NaH}_{2} \mathrm{PO}_{4}$ and $5.6 \mathrm{mM}$ of glucose adjusted to $\mathrm{pH} 7.4$, with $95 \% / 5 \%$ (vol/vol) oxygen-carbon dioxide mixture].

The hippocampal slices (at a thickness of $450 \mu \mathrm{m}$ ) prepared using a McIlwain tissue chopper (Campden Instruments Ltd., Loughborough, UK), transferred onto a six-well plate, and added with $10 \mathrm{ml} /$ well of aCSF (eight slices per well). The hippocampal slices were allowed to stabilize for one hour under room temperature. The diffusion of etomidate into the brain slices requires approximately an hour to reach $80 \%$ equilibration at a depth of 100 micromillimeters (12).

Slices were slowly warmed to $37^{\circ} \mathrm{C}$ and allowed to equilibrate for $60 \mathrm{~min}$ without stimulation until pharmacologic treatment. The aCSF in the chamber was maintained at $37^{\circ} \mathrm{C}$ for the experiment.

At the end of the experiments, cerebrospinal fluid was aspirated, and the slices were frozen in liquid nitrogen. The tissues were homogenized by sonication in $100 \mu \mathrm{l}$ of ice-cold homogenization buffer, which consisted of $50 \mathrm{mM}$ of Tris-HCL (pH 7.5), $1 \mathrm{mM}$ of sodium orthovanadate, $2 \mathrm{mM}$ of ethylenediaminetetraacetic acid, $2 \mathrm{mM}$ of ethylene glycol tetraacetic acid, $1 \mathrm{mM}$ of dithiothreitol, $5 \mathrm{mM}$ of sodium pyrophosphate, $5 \mathrm{mM}$ of potassium fluoride, $100 \mathrm{nM}$ of okadaic acid, 0.5\% IGEPAL CA-630 (Np-40), and protease inhibitors $(5 \mu \mathrm{g} / \mathrm{ml}$ of leupeptin, $5 \mu \mathrm{g} / \mathrm{ml}$ of aprotinin, $5 \mu \mathrm{g} / \mathrm{ml}$ of pepstatin and $5 \mu \mathrm{g} / \mathrm{ml}$ of chymostatin), and boiled for five min. The homogenates were stored at $-70^{\circ} \mathrm{C}$ until processing.

Chemicals and anesthetics. The effects of the following pharmacological and anesthetic agents on CREB phosphorylation were studied alone or in combination with the following agents: Propofol (1 nM-100 $\mu \mathrm{M}$; AstraZeneca, London, UK), etomidate (1 nM-100 $\mu \mathrm{M}$; Enhua Pharmaceuticals, Xuzhou, China), ketamine (1 nM-100 $\mu \mathrm{M}$; SBPC, Shanghai, China), midazolam (1 nM-100 $\mu \mathrm{M}$; Roche, Basel, Switzerland), NMDA (1 mM; Sigma, St. Louis, MO), MK801 (10 $\mu \mathrm{M}$; Sigma), chelerythrine (an inhibitor of PKC, $100 \mu \mathrm{M}$, Merck, Kenilworth, NJ), phorbol 12-myristate 13-acetate (PMA, an activator of PKC, $0.1 \mu \mathrm{M}$; Sigma), carbachol [100 $\mu \mathrm{M}$, an activator of PLC; Sigma], U73122 (50 $\mu \mathrm{M}$, an inhibitor of PLC; Sigma), and PD $98059(20 \mu \mathrm{M}$, an inhibitor of MEK; Sigma). Anesthetics were applied for $60 \mathrm{~min}$, while chelerythrine, PMA, carbachol, U73122, MK801, NMDA and PD 98059 were pre-incubated for one hour before adding any other anesthetics.

In the time-response experiment, hippocampi in one group was continuously exposed to $5 \mu \mathrm{M}$ of propofol for $1,2,5,7,9,12$, 15,30 and $60 \mathrm{~min}$, respectively, while hippocampi in the other group was incubated for five min only, and washed thoroughly with plain aCSF for 2, 4, 7, 10 and $25 \mathrm{~min}$, respectively, in order to determine the recovery of CREB phosphorylation.

Immunoblot analysis. Protein concentration in the homogenates was determined by bicinchoninic acid-based assay using bovine serum albumin as a standard. Equal amounts of protein $(50 \mu \mathrm{g})$ were separated on $10 \%$ polyacrylamide gel in the presence of sodium dodecyl sulphate, and transferred onto nitrocellulose membranes (Bio-Rad Laboratories, Inc., Hercules, CA, USA). The blots were blocked with $10 \%$ non-fat dried milk in phosphate buffered saline with $0.1 \%$ Tween-20 for one hour at room temperature with agitation. Then, the membranes were incubated with rabbit anti-phosphor-CREB antibody (1:800; Cell Signaling Technology, Beverly, MA, USA) at $4^{\circ} \mathrm{C}$ overnight. Next, horseradish peroxidase-conjugated anti-rabbit IgG (Chemicon, Temecula, CA, USA) was used at a dilation of 1:5,000 and the immune complex was detected by enhanced chemiluminescence western blotting detection reagents (Chemicon). In order to determine the percentage of phosphorylated CREB, the membranes were stripped and incubated with rabbit anti-CREB antibody (1:800; Cell Signaling Technology), and processed, as aforementioned. Immunoreactive bands were quantified using a computer-assisted densitometer, and expressed as a ratio between active CREB signal and total CREB.

Statistical analysis. Statistical analysis was performed on raw data using one-way analyses of variance (ANOVA), and statistical differences between the control and experimental groups were determined using the least significant difference procedure for multiple comparisons. $\mathrm{P}<0.05$ was considered to indicate a statistically significant difference. Data (mean \pm standard deviation) were normalized against the $\mathrm{P}-\mathrm{CREB} /$ total-CREB ratio of the controls.

\section{Results}

Propofol, etomidate, ketamine and midazolam inhibited the phosphorylation of CREB. In order to evaluate the effects of propofol, etomidate, ketamine and midazolam on the 


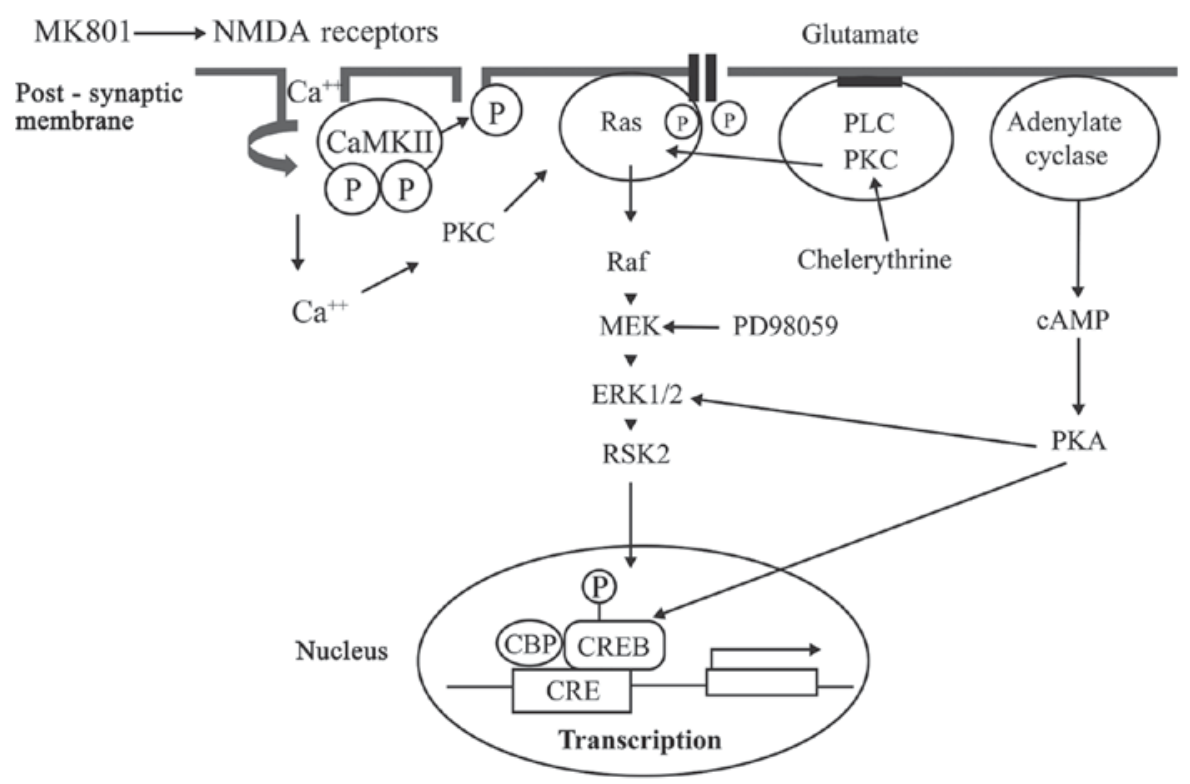

Figure 1. Schematic diagram of the putative pathways involved in CREB phosphorylation in the hippocampus. CAMKII, $\mathrm{Ca}^{2+} / \mathrm{CaM}^{-\mathrm{dependent}}$ protein kinase; CREB, cAMP-responsive element binding protein; PKC, protein kinase C; PLC, phospholipase C.

phosphorylation of CREB, western blot analysis was performed on the hippocampus slices exposed to a range of doses of individual drugs. The anesthetics used at these concentrations markedly reduced the phosphorylation of CREB at Ser133 in a dose-dependent manner (Fig. 2).

Next, it was determined whether the inhibition of CREB phosphorylation by anesthetics was reversible using propofol, which is a most commonly used intravenous anesthetic. One group of hippocampi were continuously exposed to $5 \mu \mathrm{M}$ of propofol for 1, 2, 5, 7, 9, 12, 15, 30 and $60 \mathrm{~min}$, while the other group was challenged for five min only. These were thoroughly washed and analyzed in parallel for CREB phosphorylation. In these results, exposure to $5 \mu \mathrm{M}$ of propofol induced a reduction in CREB phosphorylation, which proportionally decreased with exposure time. Therefore, a 60-minute exposure to stimulating agents was selected for further experiments. In contrast, the removal of propofol after five min of exposure resulted in the recovery of CREB phosphorylation starting from the seven-minute time point (Fig. 3).

Previous studies have demonstrated the involvement of kinase receptor pathways in the interference with cognition by intravenous anesthetics (13). Therefore, the agonists and antagonists of PKC, PLC, MEK and NMDA receptors were used in this study to characterize the functional importance of individual pathways. The inhibition of PKC by chelerythrine $(100 \mu \mathrm{M})$ resulted in a $50.3 \%$ decrease in CREB phosphorylation $(\mathrm{P}<0.05)$, and revealed the additive effects of the anesthetic-induced decrease in CREB phosphorylation (Fig. 4). The activation of PKC by PMA $(0.1 \mu \mathrm{M})$ induced a $65.9 \%$ decrease in CREB phosphorylation $(\mathrm{P}<0.05)$, showing no effects on the anesthetic-induced decrease in CREB phosphorylation (data not shown).

NMDA (1 mM) induced a weak but not significant reduction in CREB phosphorylation (Fig. 5). This completely blocked the etomidate-induced decrease in CREB phosphorylation, but only partially suppressed the effects of other anesthetic agents (Fig. 5).
In contrast, an NMDA receptor antagonist, MK801 $(10 \mu \mathrm{M})$, was ineffective in blocking the anesthetic-induced decrease in CREB phosphorylation. Moreover, the inhibition of PLC by U $73122(50 \mu \mathrm{M})$ and the activation of PLC by carbachol $(100 \mu \mathrm{M})$ also had no effects on the anesthetic-induced suppression of CREB phosphorylation. PD-98059 (an inhibitor of MEK, $20 \mu \mathrm{M}$ ) induced a significant decrease in CREB phosphorylation by $43.7 \%(\mathrm{P}<0.05)$, and revealed an additive or synergistic influence on the propofol- and a ketamine-induced decrease in CREB phosphorylation (Fig. 6).

\section{Discussion}

In the present study, it was shown that clinically relevant concentrations of intravenous anesthetic agents decreased the phosphorylation of CREB in mice hippocampal slices. These effects are likely to be mediated indirectly via the NMDA receptor, PKC and MAPK/ERK signaling pathways. These present findings support the notion that the phosphorylation of CREB represents a target for anesthetic action in the central nervous system.

Cognitive side-effects such as emergence agitation (EA), postoperative delirium (POD) and POCD do not infrequently complicate postoperative care, especially in elderly and fragile patients (14). POCD is a recognized clinical entity characterized with cognitive deficits after anesthesia and surgery, especially in elderly patients (15).

Recent evidence has indicated that propofol and midazolam impair memory for aversive and non-aversive experiences at equianxiolytic doses that do not produce locomotor impairment in rats (16). In humans, ketamine selectively affects working, episodic and procedural memory, but not perceptual priming, attention, or executive functioning. ${ }^{9}$ These findings suggest that intravenous anesthetics disrupt memory formation, and may potentially suppress the activity of transcription regulators that are considered to contribute to memory processing. Transcriptional factor CREB is 

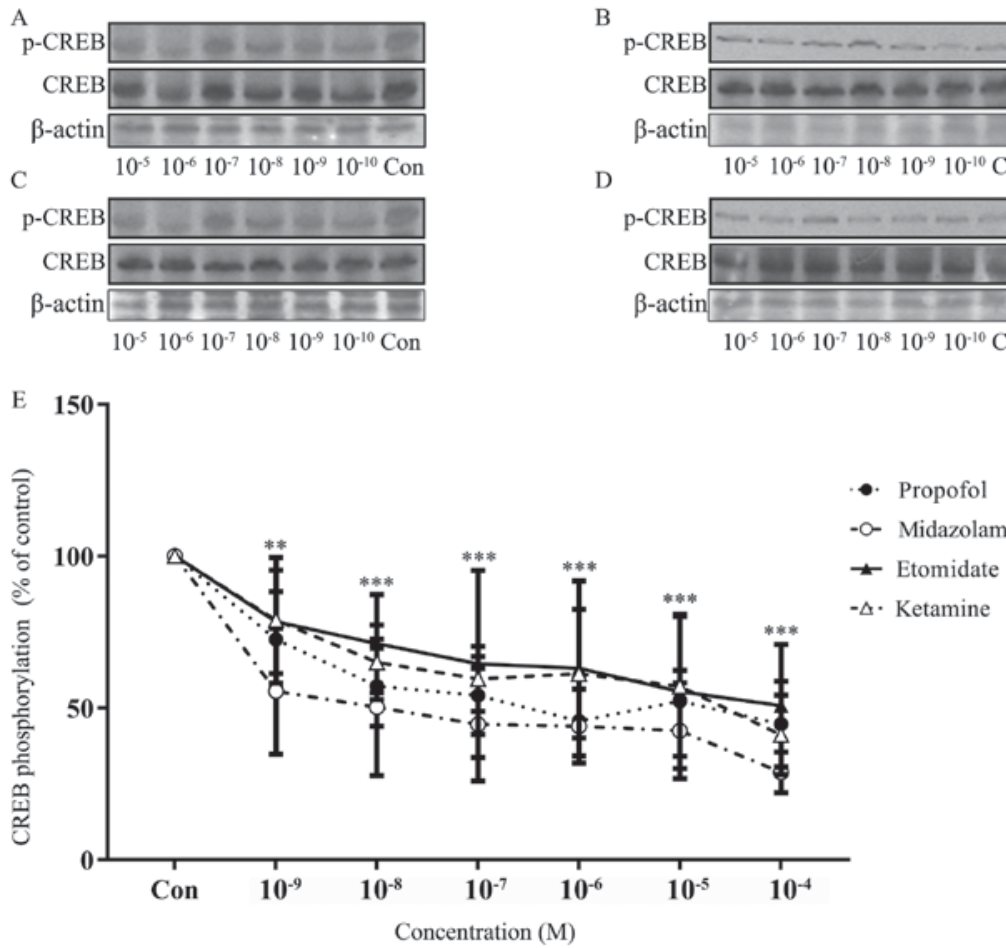

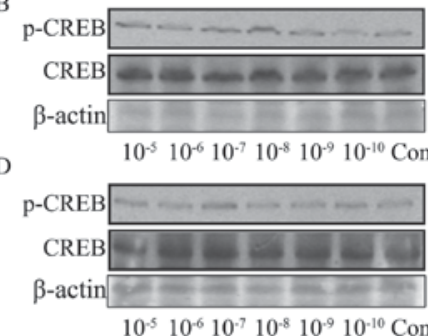

\section{.}




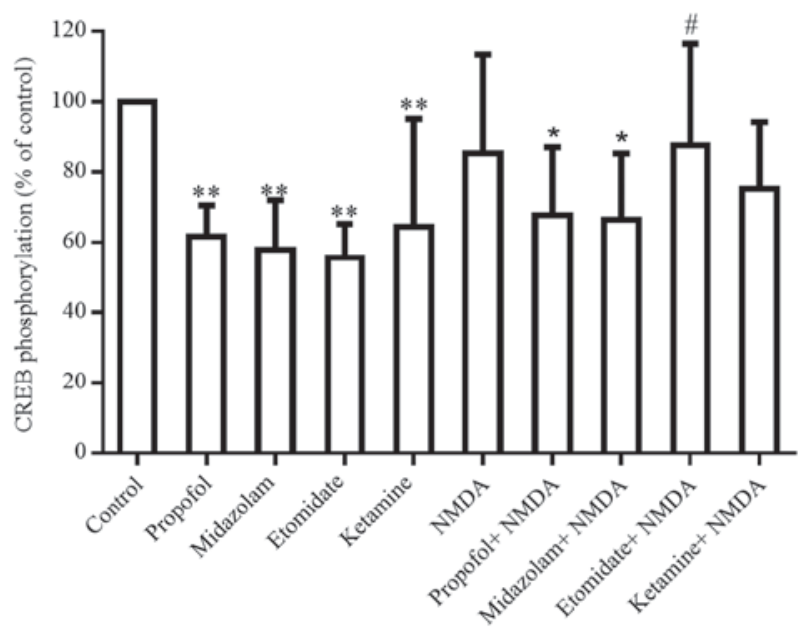

Figure 5. Effect of NMDA on the anesthetic-induced decrease in CREB phosphorylation in mice hippocampal slices. Data (mean $\pm \mathrm{SD}, n=6$ ) were expressed as a fractional decrease from the basal phosphorylation (control=100\%). Anesthetics and pharmacological agents were used at the following concentrations: Propofol, midazolam, etomidate, ketamine: $5 \mu \mathrm{M}$; NMDA: 1 mM. ${ }^{*} \mathrm{P}<0.05 ;{ }^{* *} \mathrm{P}<0.01$ vs. controls; ${ }^{*} \mathrm{P}<0.01$ vs. anesthetic-induced CREB phosphorylation. NMDA, N-Methyl-D-Aspartate; CREB, cAMP response-element binding protein.

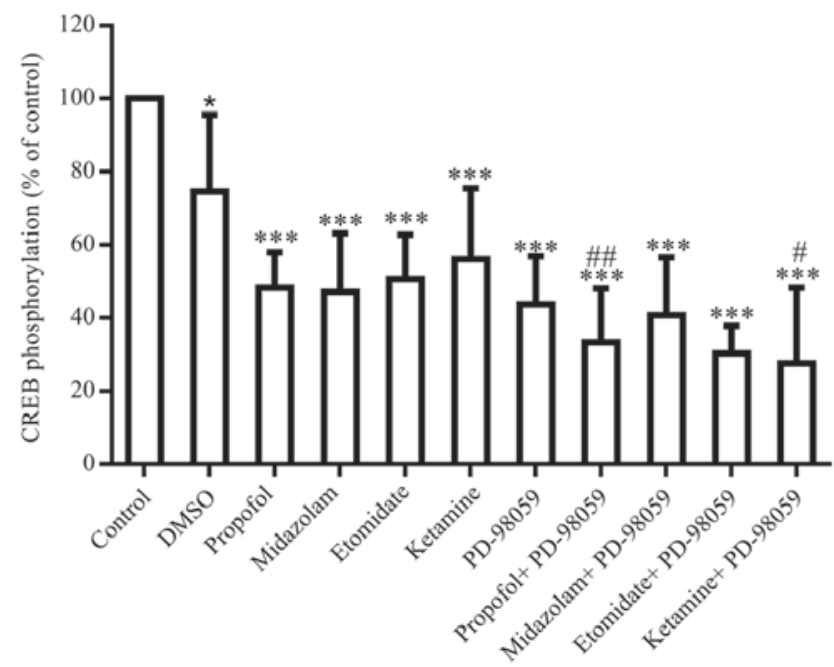

Figure 6. Effect of PD-98059 on the anesthetic-induced decrease in CREB phosphorylation in mice hippocampal slices. Data (mean $\pm \mathrm{SD}, n=6$ ) were expressed as a fractional decrease from basal phosphorylation (control=100\%). Anesthetics and pharmacologic agents were used at the following concentrations: Propofol, midazolam, etomidate, ketamine: $5 \mu \mathrm{M}$; PD-98059: $20 \mu \mathrm{M}$. ${ }^{*} \mathrm{P}<0.05,{ }^{* * * *} \mathrm{P}<0.001$ vs. controls; ${ }^{\#} \mathrm{P}<0.05 ;{ }^{\# \#} \mathrm{P}<0.01$ vs. anesthetic-induced CREB phosphorylation. CREB, cAMP response-element binding protein.

of desensitization of its effects over time and the reversibility of the propofol-induced inhibition of CREB phosphorylation further support the relevance of these present findings to anesthesia.

CREB is a vital part of many intracellular signaling events that regulate multiple neural functions. Human recombinant CREB can be phosphorylated by cAMP-dependent protein kinase and PKC in vitro (20), but preferentially at distinct serine residues. Two serines located in the basic region of CREB, Ser-340 and Ser-367, are the major PKC phosphorylation sites (20).
It has been previously shown that CREB phosphorylation is principally regulated by $\mathrm{PKC}$ in immature oligodendrocytes (21), and the inhibition of PKC blocks the retinoic acid-mediated activation of CREB (22). The PKC family consists of several members, which can be divided into three major groups: Classical PKC $(\alpha, \beta I, \beta I I$ and $\gamma)$, novel PKC $(\delta, \varepsilon, \eta$ and $\theta)$, and atypical PKC ( $\zeta$ and $\iota / \lambda)(23)$. GF 109203X inhibited the conventional isoforms and novel isoforms of PKC (24,25). A significant decrease in CREB phosphorylation was also observed with the pre-treatment of $1 \mu \mathrm{M}$ of GF $109203 \mathrm{X}$, indicating that the conventional and novel isoforms of PKC are responsible for CREB phosphorylation after OX2R activation in CHO cells (26). The phosphorylation of CREB at serine-133 induced by signaling through the B-cell antigen receptor requires $\mathrm{PKC \delta}$ (27). PKCE is implicated in cytokine-induced serine-133 phosphorylation and the activation of CREB-mediated transcription in human erythroleukemia cell line TF-1. However, $\mathrm{PKC} \varepsilon$ forms a component of the signal cascade rather than act as the genuine CREB kinase (28). Chelerythrine is also a large spectrum PKC inhibitor.

Furthermore, the apparent additive effect of PKC inhibitor chelerythrine was observed on the anesthetic-induced inhibition of CREB phosphorylation, while PKC activation by PMA revealed no obvious changes. These results suggest that PKC is responsible for the anesthetic-induced decrease in CREB phosphorylation at Ser133, while its activation had no effect. The phosphorylation of platelet protein $\mathrm{P} 47$, which is a marker of PKC activation, is markedly inhibited by ketamine $(350 \mu \mathrm{M})$ or midazolam (15 and $30 \mu \mathrm{M})(29,30)$, and there is little direct evidence on the effect of intravenous anesthetics on PKC.

Behavioral, anatomical and electrophysiological studies have shown that hippocampal NMDA receptors are involved in human memory (31). NMDA stimulation induces the rapid phosphorylation of CREB on Ser133 during the development of hippocampal neurons in culture (32). The activation of NMDA receptors by NMDA rapidly and concentration-dependently increases the number of neurons expressing phosphorylated CREB, while antagonizing NMDA signaling by MK801 reduces CREB phosphorylation (33). In addition, the transcription of NMDAR1 is regulated by the c-AMP signaling pathway, which is most likely through the binding of CREB and its activation through signal-dependent phosphorylation (34). It is now clear that neither AMPA/kainate receptors, nor NMDA receptors are sufficient to independently stimulate a second messenger pathway that leads to CREB phosphorylation (35). In the present study, it was observed that NMDA treatment induced a weak but not significant decrease in CREB phosphorylation. The NMDA treatment itself did not increase CREB phosphorylation in the present experiment. It was reported that an increase in p-CREB protein level was observed from 6-12 $\mathrm{h}$ after NMDA injection in the retina (36). Moreover, CREB phosphorylation after exposure to glutamate was shown to be dependent on CaMK II/IV in hippocampal neurons (37). However, this completely blocked the etomidate-induced decrease in CREB phosphorylation, and partially blocked the inhibition of other anesthetic agents. Lipid emulsions have been used as carriers for hypnotics such as propofol and etomidate. Lipid emulsions activate NMDA receptor channels in cortical neurons (38). It 
was observed that NMDA had an additive effect in the presence of etomidate. It is noteworthy to mention that inhibiting NMDA signaling by MK801 is not enough to block the anesthetic-induced decrease in ERK1/2 phosphorylation. This present observation supports the hypothesis that intravenous anesthetic agents may induce a decrease in CREB phosphorylation via NMDA receptors. It has been reported that there is a consecutive pathway from AMPA/kainate receptors to NMDA receptors and from NMDA receptors to L-type $\mathrm{Ca}^{2+}$ channels. AMPA/kainate receptors are involved in relieving the $\mathrm{Mg}^{2+}$ block of NMDA receptors, and NMDA receptors trigger the opening of L-type $\mathrm{Ca}^{2+}$ channels. The second messenger pathway that activates CREB phosphorylation is likely activated by $\mathrm{Ca}^{2+}$ entry through L-type $\mathrm{Ca}^{2+}$ channels (39).

The MAPK pathway is another signaling cascade that regulates CREB (39). MAPK activation is required for the phosphorylation of CREB in response to the activation of PKC, and is needed for PKA coupling to CREB phosphorylation in the CA1 area (34). Furthermore, activated MAPK increases the phosphorylation of CREB by stimulating its gene expression (40). Hence, the inhibition of ERK1/2 by PD98059 reduces CREB phosphorylation (41). It was observed that PD-98059 induced a significant decrease in CREB phosphorylation, and revealed its additive influence on the propofol- and ketamine-induced decrease in CREB phosphorylation. These results indicate that intravenous anesthetic agents may induce a decrease in CREB phosphorylation via the ERK1/2 signal transduction pathway. Propofol, midazolam and etomidate act at GABAA receptors, and ketamine act at NMDA receptors. The enhancement of GABAA receptor-mediated inhibition is a property of most general anesthetics, which is a candidate for the molecular mechanism of anesthesia $(42,43)$. Ketamine is an NMDA receptor antagonist anesthetic agent (44). Since GABAA is not related to MAPK-CREB, a GABA (A) agonist and antagonist experiment was not performed.

Taken together, clinically relevant concentrations of intravenous anesthetic agents decrease the phosphorylation of CREB in mice hippocampal slices. These effects are likely to be mediated indirectly via the NMDA receptor, PKC and ERK1/2 signaling pathways. These findings support the idea that these inhibitory effects on CREB phosphorylation may be potential mechanisms that contribute to anesthetic-induced amnesia.

\section{Competing interests}

The authors declare that they have no competing interests.

\section{References}

1. Davis N, Lee M, Lin AY, Lynch L, Monteleone M, Falzon L, Ispahany $\mathrm{N}$ and Lei S: Postoperative cognitive function following general versus regional anesthesia: A systematic review. J Neurosurg Anesthesiol 26: 369-376, 2014.

2. Androsova G, Krause R, Winterer G and Schneider R: Biomarkers of postoperative delirium and cognitive dysfunction. Front Aging Neurosci 7: 112, 2015

3. Silbert BS, Evered LA and Scott DA: Incidence of postoperative cognitive dysfunction after general or spinal anaesthesia for extracorporeal shock wave lithotripsy. Br J Anaesth 113: 784-791, 2014.
4. Moller JT, Cluitmans P, Rasmussen LS, Houx P, Rasmussen H, Canet J, Rabbitt P, Jolles J, Larsen K, Hanning CD, et al: Long-term postoperative cognitive dysfunction in the elderly ISPOCD1 study. ISPOCD investigators. International Study of Post-Operative Cognitive Dysfunction. Lancet 351: 857-861, 1998.

5. Tang N, Ou C, Liu Y, Zuo Y and Bai Y: Effect of inhalational anaesthetic on postoperative cognitive dysfunction following radical rectal resection in elderly patients with mild cognitive impairment. J Int Med Res 42: 1252-1261, 2014.

6. Middei S, Houeland G, Cavallucci V, Ammassari-Teule M, D'Amelio M and Marie H: CREB is necessary for synaptic maintenance and learning-induced changes of the AMPA receptor GluA1 subunit. Hippocampus 23: 488-499, 2013.

7. Alberini CM: Genes to remember. J Exp Biol 202: 2887-2891, 1999.

8. Yin JC and Tully T: CREB and the formation of long-term memory. Curr Opin Neurobiol 6: 264-268, 1996.

9. Johnston MV, Alemi L and Harum KH: Learning, memory, and transcription factors. Pediatr Res 53: 369-374, 2003.

10. Gao C, Che LW, Chen J, Xu XJ and Chi ZQ: Ohmefentanyl stereoisomers induce changes of CREB phosphorylation in hippocampus of mice in conditioned place preference paradigm. Cell Res 13: 29-34, 2003.

11. Zhang H, Zhang SB, Zhang QQ, Liu M, He XY, Zou Z, Sun HJ, You ZD and Shi XY: Rescue of cAMP response element-binding protein signaling reversed spatial memory retention impairments induced by subanesthetic dose of propofol. CNS Neurosci Ther 19: 484-493, 2013.

12. Benkwitz C, Liao M, Laster MJ, Sonner JM, Eger EI II and Pearce RA: Determination of the EC50 amnesic concentration of etomidate and its diffusion profile in brain tissue: Implications for in vitro studies. Anesthesiology 106: 114-123, 2007.

13. Praticò C, Quattrone D, Lucanto T, Amato A, Penna O, Roscitano C and Fodale V: Drugs of anesthesia acting on central cholinergic system may cause post-operative cognitive dysfunction and delirium. Med Hypotheses 65: 972-982, 2005.

14. Jildenstål PK, Rawal N, Hallén JL, Berggren L and Jakobsson JG: Perioperative management in order to minimise postoperative delirium and postoperative cognitive dysfunction: Results from a Swedish web-based survey. Ann Med Surg (Lond) 3: 100-107, 2014.

15. Jia M, Liu WX, Sun HL, Chang YQ, Yang JJ, Ji MH, Yang JJ and Feng CZ: Suberoylanilide hydroxamic acid, a histone deacetylase inhibitor, attenuates postoperative cognitive dysfunction in aging mice. Front Mol Neurosci 8: 52, 2015.

16. Pain L, Angst MJ, LeGourrier L and Oberling P: Effect of a nonsedative dose of propofol on memory for aversively loaded information in rats. Anesthesiology 97: 447-453, 2002.

17. Mizuno M, Yamada K, Maekawa N, Saito K, Seishima M and Nabeshima T: CREB phosphorylation as a molecular marker of memory processing in the hippocampus for spatial learning. Behav Brain Res 133: 135-141, 2002.

18. Taubenfeld SM, Wiig KA, Monti B, Dolan B, Pollonini G and Alberini CM: Fornix-dependent induction of hippocampal CCAAT enhancer-binding protein [beta] and [delta] co-localizes with phosphorylated cAMP response element-binding protein and accompanies long-term memory consolidation. J Neurosci 21: 84-91, 2001.

19. Josselyn SA and Nguyen PV: CREB, synapses and memory disorders: Past progress and future challenges. Curr Drug Targets CNS Neurol Disord 4: 481-497, 2005.

20. Sakurai A, Maekawa T, Sudo T, Ishii S and Kishimoto A: Phosphorylation of cAMP response element-binding protein, CRE-BP1, by cAMP-dependent protein kinase and protein kinase C. Biochem Biophys Res Commun 181: 629-635, 1991.

21. Shiga H, Yamane Y, Kubo M, Sakurai Y, Asou H and Ito E: Differentiation of immature oligodendrocytes is regulated by phosphorylation of cyclic AMP-response element binding protein by a protein kinase $\mathrm{C}$ signaling cascade. J Neurosci Res 80: 767-776, 2005.

22. Aggarwal S, Kim SW, Cheon K, Tabassam FH, Yoon JH and Koo JS: Nonclassical action of retinoic acid on the activation of the cAMP response element-binding protein in normal human bronchial epithelial cells. Mol Biol Cell 17: 566-575, 2006.

23. Steinberg SF: Structural basis of protein kinase C isoform function. Physiol Rev 88: 1341-1378, 2008. 
24. Toullec D, Pianetti P, Coste H, Bellevergue P, Grand-Perret T, Ajakane M, Baudet V, Boissin P, Boursier E, Loriolle F, et al: The bisindolylmaleimide GF $109203 \mathrm{X}$ is a potent and selective inhibitor of protein kinase C. J Biol Chem 266: 15771-15781, 1991.

25. Le Panse R, Coulomb B, Mitev V, Bouchard B, Lebreton C and Dubertret L: Differential modulation of human fibroblast and keratinocyte growth by the protein kinase C inhibitor GF 109203X. Mol Pharmacol 46: 445-451, 1994.

26. Guo Y and Feng P: OX2R activation induces PKC-mediated ERK and CREB phosphorylation. Exp Cell Res 318: 2004-2013, 2012.

27. Blois JT, Mataraza JM, Mecklenbraüker I, Tarakhovsky A and Chiles TC: B cell receptor-induced cAMP-response element-binding protein activation in $\mathrm{B}$ lymphocytes requires novel protein kinase Cdelta. J Biol Chem 279: 30123-30132, 2004.

28. Gubina E, Luo X, Kwon E, Sakamoto K, Shi YF and Mufson RA: betac cytokine receptor-induced stimulation of cAMP response element binding protein phosphorylation requires protein kinase $\mathrm{C}$ in myeloid cells: A novel cytokine signal transduction cascade. J Immunol 167: 4303-4310, 2001.

29. Chang Y, Chen TL, Wu GJ, Hsiao G, Shen MY, Lin KH, Chou DS, Lin CH and Sheu JR: Mechanisms involved in the antiplatelet activity of ketamine in human platelets. J Biomed Sci 11: 764-772, 2004.

30. Hsiao G, Shen MY, Chou DS, Chang Y, Lee LW, Lin CH and Sheu JR: Mechanisms of antiplatelet and antithrombotic activity of midazolam in in vitro and in vivo studies. Eur J Pharmacol 487: 159-166, 2004

31. Grunwald T, Beck H, Lehnertz K, Blümcke I, Pezer N, Kurthen M, Fernández G, Van Roost D, Heinze HJ, Kutas M and Elger CE: Evidence relating human verbal memory to hippocampal N-methyl-D-aspartate receptors. Proc Natl Acad Sci USA 96: 12085-12089, 1999.

32. Sala C, Rudolph-Correia S and Sheng M: Developmentally regulated NMDA receptor-dependent dephosphorylation of cAMP response element-binding protein (CREB) in hippocampal neurons. J Neurosci 20: 3529-3536, 2000.

33. Mao L and Wang JQ: Interactions between ionotropic and metabotropic glutamate receptors regulate cAMP response element-binding protein phosphorylation in cultured striatal neurons. Neuroscience 115: 395-402, 2002.
34. Lau GC, Saha S, Faris R and Russek SJ: Up-regulation of NMDAR1 subunit gene expression in cortical neurons via a PKA-dependent pathway. J Neurochem 88: 564-575, 2004.

35. Rajadhyaksha A, Barczak A, Maci'as W, Leveque JC, Lewis SE and Konradi C: L-type $\mathrm{Ca}(2+)$ channels are essential for glutamate-mediated CREB phosphorylation and c-fos gene expression in striatal neurons. J Neurosci 19: 6348-6359, 1999.

36. Takeda H, Kitaoka Y, Hayashi Y, Kumai T, Munemasa Y, Fujino H, Kobayashi S and Ueno S: Calcium/calmodulin-dependent protein kinase II regulates the phosphorylation of CREB in NMDA-induced retinal neurotoxicity. Brain Res 1184: 306-315, 2007.

37. Mabuchi T, Kitagawa K, Kuwabara K, Takasawa K, Ohtsuki T, Xia Z, Storm D, Yanagihara T, Hori $\mathrm{M}$ and Matsumoto $\mathrm{M}$ : Phosphorylation of cAMP response element-binding protein in hippocampal neurons as a protective response after exposure to glutamate in vitro and ischemia in vivo. J Neurosci 21: 9204-9213, 2001.

38. Weigt HU, Georgieff M, Beyer C and Föhr KJ: Activation of neuronal N-methyl-D-aspartate receptor channels by lipid emulsions. Anesth Analg 94: 331-337, 2002.

39. Villarreal JS and Barea-Rodriguez EJ: ERK phosphorylation is required for retention of trace fear memory. Neurobiol Learn Mem 85: 44-57, 2006

40. Roberson ED, English JD, Adams JP, Selcher JC, Kondratick C and Sweatt JD: The mitogen-activated protein kinase cascade couples PKA and PKC to cAMP response element binding protein phosphorylation in area CA1 of hippocampus. J Neurosci 19: 4337-4348, 1999

41. Alonso M, Vianna MR, Izquierdo I and Medina JH: Signaling mechanisms mediating BDNF modulation of memory formation in vivo in the hippocampus. Cell Mol Neurobiol 22: 663-674, 2002.

42. Li GD, Chiara DC, Cohen JB and Olsen RW: Numerous classes of general anesthetics inhibit etomidate binding to gamma-aminobutyric acid type A (GABAA) receptors. J Biol Chem 285: 8615-8620, 2010.

43. Straub CJ, Lau HM, Parlato R, Schuetz G, Fritschy JM and Rudolph U: Bidirectional regulation of intravenous general anesthetic actions by $\alpha 3$-containing $\gamma$-aminobutyric acid A receptors Anesthesiology 118: 562-576, 2013.

44. Dutta A, McKie S and Deakin JFW: Ketamine and other potential glutamate antidepressants. Psychiatry Res 225: 1-13, 2015. 